Creative Commons User License: CC BY-NC-ND

Abstracted by: EBSCOhost, Electronic Journals Service (EJS),

Google Scholar, Journal Seek, Scientific Commons,

Food and Agricultural Organization (FAO), CABI and Scopus

http://eoi.citefactor.org/10.11226/v24i4
Journal of Agricultural Extension

Vol. 24 (4) October, 2020

ISSN(e): 24086851; ISSN(Print); 1119944X

http://journal.aesonnigeria.org

http://www.ajol.info/index.php/iae

Email: editorinchief@aesonnigeria.org

\title{
Smallholder Farmers Willingness to Pay for Privatized Agricultural Extension Services in Tigray National Regional State, Ethiopia
}

https://dx.doi.org/10.4314/jae.v24i4.4

\author{
Kidane Tesfay Gebreegziabher \\ Department of Rural Development and Agricultural Extension, Mekelle University, P.O.Box \\ 231, Mekelle, Ethiopia. \\ Email:kidanetesfay21@gmail.com \\ $+251914760115$
}

\section{Gidey Kidu Mezgebo}

Department of Agriculture and Resource economics, Mekelle University, P.O.Box 231, Mekelle, Ethiopia.

Email :gideykidu2005@gmail.com

$+251914127853$

*Corresponding author: kidanetesfay21@gmail.com or kidane.tesfay@mu.edu.et

\section{Abstract}

This study assessed farmers' willingness to pay for privatization of agricultural extension services and examined factors that determine willingness to pay for those services. Multistage sampling procedure was used in selecting 240 households. Data were collected using household survey, focus group discussion and key informant interview tools. Data were analyzed using percentage and logit model. Results showed that $58 \%$ of the respondents were willing to pay for the privatization of agricultural extension services. Farm size, age, family size, credit access, frequency of extension contact and income were significantly influenced farmers' willingness to pay for privatization of agricultural extension services. Privatization of agricultural extension services encourages graduates of agricultural sciences to launch consultancy firms and this engenders professional entrepreneurship. Number of visits, socioeconomic, and institutional factors must be given emphasis for privatizing the agricultural extension service in Ethiopia. Moreover, government should launch privatization parallel to the public agricultural extension services

Key words: Agricultural extension service, willingness, privatization. Ethiopia

\section{Introduction}

Agriculture is the mainstay of the economy in sub-Saharan Africa and it is recognized for its immense contributions to food security, poverty reduction, and employment generation (Modi, 2019). Despite its contribution to agricultural growth and poverty reduction, there has been a decline in public spending on agriculture in most developing countries (Fontan \& Mughal, 2019). In response to this, agricultural extension services (AESs) have been the theme of reform widely employed and practiced in Africa including Ethiopia (Cai, Jia, Hu, \& Zhang, C, 2020). This was aimed 
Creative Commons User License: CC BY-NC-ND

Abstracted by: EBSCOhost, Electronic Journals Service (EJS), Google Scholar, Journal Seek, Scientific Commons,

Food and Agricultural Organization (FAO), CABI and Scopus
Journal of Agricultural Extension

Vol. 24 (4) October, 2020

ISSN(e): 24086851; ISSN(Print); 1119944X

http://journal.aesonnigeria.org

http://www.ajol.info/index.php/iae

Email: editorinchief@aesonnigeria.org

at making them 'pluralistic' and effective in achieving the needs of smallholder farmers and other clients (Dhehibi, 2018; Klerkx, Landini, \& Santoyo, 2016).

The AESs realizes the multitude of different actors engaged in supporting and facilitating the access of farmers to technical backstopping on knowledge, skills, modern technologies, credit, markets, information and other rural services (Davis, Swanson \& Amudavi, 2019). As such, AESs contributes to local development and improved rural lives in different modalities: by technology transfer from agricultural bureaus to farmers, and reporting farmers' feedback to agricultural experts; through demonstration of improved technologies (such as improved crop varieties, fertilizers, insecticides); by conducting seminars and demand driven training; and by advising farmers on their farm and problem-solving mechanisms (George, Duncan, David, \& Johnson, 2018). Regarding the historical background of AESs, there is visible change from a simple technology transfer paradigm to participatory approaches to market-oriented and cost-sharing models (Berhane, Ragasa, Abate, \& Assefa, 2018). However, it is also noted that a combined approach can be utilized as per the priorities of the clients as well as the institutional capacity of the implementing organizations.

Many developed nations have followed a paradigm shift towards decentralization, contracting/outsourcing, public-private partnerships, privatization, and increased involvement of non-governmental organizations (NGOs) in AES provision (Zwane, 2016). This has resulted in cost effective public expenditures on these services, and greater engagement of private and other stakeholders. Moreover, studies from other African countries indicate that private extension service is better than the public in delivering quality service (Sylla, Al-Hassan, Egyir, \& Anim-Somuah, 2019). Due to this, public funded extension service is criticized for its poor service delivery. Thus, there is a need to make paradigm shift to fee-based service provision arrangement (Uddin, Gao \& Mamun-Ur-Rashid, 2016), where clients of AESs share, or pay in full, the cost of services

However, in most of the low income countries, technical information and technology provisioning are made through the public agricultural advisory systems (Rada \& Fuglie, 2019). The Ethiopian national AES is not an exception to this. Since its formal commencement in the early 1950s, it has been provided and financed primarily by the public sector. The "one-size-fits-all" approach which gives little consideration for the socioeconomic and biophysical variations across the country and contradicts with the "best-fits" approach to agricultural advisory services is widely practiced (AAS) (Gerba, Girma, Till ,Kristof Assche., \& Anna-Katharina , 2017). Public AESs in Ethiopia is affected by current economic crisis, and budget limitations. Due to this and other problems, AES are becoming inefficient and not responsive to the diverse needs of smallholder farmers. Several studies have been conducted in Ethiopia regarding public advisory services delivery (Atinaf, M., Molla, A., Karanasios, and Anteneh, 2020; Abate, G. T., Bernard, T., Makhija, S., 2019; Spielman, 2019; Beyene, 2017) with limited evidence on privatization except Wordofa, (2019) and Tolera, et al., (2014), who studied on farmers' readiness to embrace cost-sharing agricultural extension approach and factors affecting farmers' willingness to pay for agricultural extension services respectively. Besides, there is a shortage of empirical 
Creative Commons User License: CC BY-NC-ND

Abstracted by: EBSCOhost, Electronic Journals Service (EJS)

Google Scholar, Journal Seek, Scientific Commons,

Food and Agricultural Organization (FAO), CABI and Scopus
Journal of Agricultural Extension

Vol. 24 (4) October, 2020

ISSN(e): 24086851; ISSN(Print); 1119944X

http://journal.aesonnigeria.org

http://www.ajol.info/index.php/iae

Email: editorinchief@aesonnigeria.org

evidence to recommend which components of AESs to privatize in the future. Based on this, it is important to recommend alternative modality of providing and financing AESs. Therefore, this study examined determinants of farmers' willingness on co-financing the provision of AESs as a new scheme.

\section{Methodology}

Tigray regional state is located in the drier northern part of Ethiopia. It is located between latitude $14^{0} 1^{\prime}$ ' north and longitude $38^{0} 18^{\prime}$ east. The region shares common borders with Eritrea in the north, the State of Afar in the east, the State of Amhara in the south, and the Republic of Sudan in the west. Tigray covers an area of 53,000 kilometers $^{2}$ and has a total population of approximately 5 million. The region has six administration zones: western, north western, central, eastern, southeaster, and Mekelle special zone. The eastern and central zones are densely populated as compared to a sparsely populated western zone. Administratively, the Tigray region has 35 districts, 12 town districts, and 665 kebeles $^{1}$. Each district is subdivided into kebeles. The landform is complex, composed of highlands in the range of 2,300-3,200 meters above sea level (MASL), lowland plains with an altitude range of less than 500-1,500 MASL, mountain peaks as high as 3,935 MASL, and high to moderate relief hills $(1,600-2,200 \mathrm{MASL})$.

The study was carried out in four rural districts of the region namely Raya Azebo,Enderta, Hintalowajerat, and KilteAwlaelo.These four districts were purposefully selected due to their high level of participation in terms of extension services, commercial orientation, access to transportation and market infrastructure, and access to irrigation facilities. Similarly, one kebele from each district was selected. Second, the list of farmers was obtained from the respective kebeles and the sample size were determined using the single population proportion formula. Accordingly, out of the 6724 households heads, a sample of 246 households was selected using simple random sampling technique. Finally, the sample households to be selected from each sample kebeles were determined proportionally. Based on this 54 from wargiba,49 from hiwane,104 from aroto, and 39 from mesanu kebeles were selected. Questionnaires were distributed to 246 farm households out of whch $6(2.4 \%)$ questionnaires were incomplete. Thus, data analysis as based on 240 respondents.

Data consists of socioeconomic, demographic and institutional characteristics of the households, current sources of information, the nature and extent of contact between the farmers and public extension agents, and farmer willingness to pay (WTP) for privatization of agricultural extension service were collected using household survey. To get opinions and perceptions on the willingness to pay four focused group discussions and three key informants' interview were conducted.

Percentages was used for assessing willingness to pay for agricultural extension services. Logit model was used to analyse the determinants of willingness to pay for agricultural extension services.

\footnotetext{
${ }^{1}$ Kebele refers the smallest administrative unit in Ethiopia.
} 
Creative Commons User License: CC BY-NC-ND

Abstracted by: EBSCOhost, Electronic Journals Service (EJS), Google Scholar, Journal Seek, Scientific Commons,

Food and Agricultural Organization (FAO), CABI and Scopus
Journal of Agricultural Extension

Vol. 24 (4) October, 2020

ISSN(e): 24086851; ISSN(Print); 1119944X

http://journal.aesonnigeria.org

http://www.ajol.info/index.php/iae

Email: editorinchief@aesonnigeria.org

The specification of the logit model was as follows:

The model in its empirical form is based on the assumption that the probability of willingness to pay, Pi relies on a vector of known variables (Xij) and a vector of unknowns, $\beta$. Thus:

$P i=F(Z i)=F(\alpha+\beta X i)=1 /[1+\exp (-Z i)] \ldots(1)$

Where:

$F(Z i)=$ The standard normal density function for the possible values of the index Zi.;

$\mathrm{Pi}=$ the probability of "willingness to pay for extension services;"

$\beta=$ regression parameters to be estimated;

$\mathrm{X}=$ set of explanatory variables;

$\alpha=$ regression intercept; and

$\beta X i=a$ combination of explanatory variables, such that:

$Z i=\log [P i /(1-P i)]=\beta 0+\beta 1 X 1+\ldots+\beta n X n+\varepsilon \ldots(2)$

Where:

$\mathrm{i}=1,2 \ldots \mathrm{n}$ are observations;

$\mathrm{Zi}=$ the natural logarithm of choice for the $\mathrm{ith}^{\text {th }}$ observation;

$\mathrm{Xn}=$ the $\mathrm{n}^{\text {th }}$ explanatory observation; and $\varepsilon=$ the error or disturbance term.

The variable, $\mathrm{Zi}$ in equation 2 is the logarithm of the probability that a particular

Choice (for example willing to pay).

\section{Results and Discussions}

\section{Farmers Willingness to Pay for Agricultural Extension Services}

The data obtained indicated that about $58 \%$ of sampled farmers agreed to pay for current extension service provided by development agents. Furthermore, out of these farmers agreed to pay between 2600 Ethiopian Birr $\left(\mathrm{ETB}^{2}\right)-3250 \mathrm{ETB}$, on average they were willing to receive annually 10 times advice, twice demonstration and six times training per year. 
Creative Commons User License: CC BY-NC-ND

Abstracted by: EBSCOhost, Electronic Journals Service (EJS), Google Scholar, Journal Seek, Scientific Commons,

Food and Agricultural Organization (FAO), CABI and Scopus

http://eoi.citefactor.org/10.11226/v24i4
Journal of Agricultural Extension

Vol. 24 (4) October, 2020

ISSN(e): 24086851; ISSN(Print); 1119944X

http://journal.aesonnigeria.org

http://www.ajol.info/index.php/iae

Email: editorinchief@aesonnigeria.org

\section{Types of Agricultural Extension and Willingness to Pay}

The major services indicated by farmers that they preferred to pay were advice on animal health $(57.5 \%)$, improved crop production (56.3\%), field crop row planting $(47.1 \%)$, Crop protection $(45 \%)$ and horticultural crops improved varieties $(36 \%)$ (Table 1).

Table 1: Current agricultural extension services which are ready to privatize

\begin{tabular}{ll}
\hline Agricultural extension & services \\
\hline Improved crop varieties & 56.3 \\
Crop protection & 45.8 \\
Field crop row planting & 47.1 \\
animal forage feed formulation and feed treatment & 43.8 \\
techniques & \\
veterinary service & 57.5 \\
Horticultural crops improved varieties & 36.3 \\
horticultural crops plant protection & 38.8 \\
\hline
\end{tabular}

Similarly, it was revealed that farmers were willing to pay under the condition of profit guaranteed specific advises for their farm, if payment made after production. In addition, from the key informant interview, it was indicated that farmers were convinced on fee based Agricultural extension services for the betterment of the service delivery. Regarding the amount of money, if the service can satisfy their needs, they can pay even a lot depending on the improvement on their farm income. Farmers preferred to pay in group/cooperative. While few indicated they want to pay individually.

\section{Determinants of Willingness to Pay for Agricultural Extension Services}

Table 2 shows that age was significant $(p \leq 0.05)$ and negatively influences the willingness to pay for agricultural extension services. This indicates as age increases by 1 year, the willingness to pay decreases by $13.9 \%$. This implies that as the farmer grows older, his/her WTP for AESs decreases. It is believed that older people prefer to keep tradition and therefore they are less likely to support the idea of paying for extension services. 
Creative Commons User License: CC BY-NC-ND

Abstracted by: EBSCOhost, Electronic Journals Service (EJS), Google Scholar, Journal Seek, Scientific Commons,

Food and Agricultural Organization (FAO), CABI and Scopus

http://eoi.citefactor.org/10.11226/v24i4
Journal of Agricultural Extension

Vol. 24 (4) October, 2020

ISSN(e): 24086851; ISSN(Print); 1119944X

http://journal.aesonnigeria.org

http://www.ajol.info/index.php/iae

Email: editorinchief@aesonnigeria.org

Table 2: Determinants of willingness to pay for agricultural extension services

\begin{tabular}{lll}
\hline Determinants of willingness to pay & Coefficients & $\mathbf{P}>|\mathbf{Z}|$ \\
\hline Age (in years) & -0.139 & $0.065^{*}$ \\
Education level of the household & -0.056 & 0.601 \\
Gender of the house hold head & -0.508 & 0.693 \\
Family size & -0.1727991 & $0.035^{\star * *}$ \\
Extension contact & 0.7414489 & $0.049^{* * *}$ \\
Total livestock unit (TLU) & 0.270 & 0.293 \\
Farm experience of the household & 0.48 & 0.520 \\
Farm size & 1.406 & $0.032^{* * *}$ \\
Income & 0.087 & $0.050^{* * *}$ \\
Irrigation use & -0.239 & 0.249 \\
Credit access & -0.999 & $0.085^{*}$ \\
\hline
\end{tabular}

logit regression $=============================>$ Prob $>$ chi2 = 0.3503 Significant level: ${ }^{*}=10 \% ;{ }^{* *}=5 \% ;{ }^{* *}=1 \%$

Number of obs $=240$ LR chi2 $(14)=15.42$ Log likelihood $=-140.55$ Pseudo R2 $=0.0520$

Contrary, young people were willing to pay because they were ready to adopt the new technologies that are provided in the extension services to improve their agricultural practices. A number of factors have been attributed to age as a factor of acceptance and investing in innovation. Young people are risk takers, are likely to be more educated, have more avenues for information, more likely to change perception and have disposable income. The result conformed with studies of Shausi, G. L., Ahmad, A. K., and Abdallah (2019), which indicated that age was negatively correlated with crop farmers willingness to pay for agricultural extension services in Tanzania.

As hypothesized, family size was significant and negatively correlated with farmers' willingness to pay for the private extension service. As the family size increases by one person, the probability of willingness to pay for extension services decreases by $25.9 \%$. This is due to the reality that the additional fee for the private extension service creates an additional burden to the household disrupting the capability of farmer's expenditure. This can create negative attitudes towards willingness to pay for advisory services. This result is consistent with the findings of Tolera, T., Temesgen, D., \& Rajan, D. S. (2014), which indicated that as household size increases, the farmer may, faces the fear to feed his family and this can create negative attitudes towards willingness to pay for advisory services in Haramaya District, Ethiopia.

Frequency of extension contact was found significant $(\mathrm{p}=0.049)$ and positively correlated with farmers' willingness to pay for the agricultural extension service at less than $5 \%$. The result shows that a one-day increase in the frequency of extension contact the willingness to pay for Agricultural extension services increases by $74 \%$. Extension service is assumed to improve farmer knowledge and skills about 
agricultural technologies. Similarly, farmers with a more frequent contact with extension agents are able to get advice and training on agricultural services. For these reasons, farmers who have frequent extension contact might be more likely willing to pay for the improved agricultural services than their counterparts. This finding is in line with Arinloye, D. D. A. A., Linnemann, A. R., Hagelaar, G., Omta, S. W. F., Coulibaly, O. N., and van Boekel, M. A. J. S.,(2016) who submitted that contact with extension services is a positive factor in pineapple farmers' willingness to pay for market information received by mobile phone in Benin.

Farm size was found significant and positively associated with household's willingness to pay for the private agricultural extension service. It was statically significant at less than $5 \%$ probability level. The marginal effect result indicates that as size of farm increases by 1 tsimad $^{3}$ willingness to pay for agricultural extension services increases by $14 \%$ from the mean. The positive association between willingness to pay for agricultural extension services and farm size indicates the presence of economics of scale. Furthermore, farm size is often used as indicator of wealth in agrarian societies and the results here could be suggesting households with large farm size are more interested to increase their produce through improving efficiency by receiving appropriate advisory service. The finding of this study conforms to Angella, N., Dick, S., and Fred, B., (2014) which indicated that the positive relationship between farm size and willingness to pay is likely because farmers with large land endowment also cultivate larger rice plots at Doho Rice Irrigation Scheme in Uganda and higher income from rice when the supply of irrigation water is adequate.

Household income was positively correlated with willingness to pay for private extension service. This was in line to the demand theory that as income of the household increases, farmers' ability to purchase additional good also increases. Households at higher income levels are willing to pay for extension services since the budget constraint becomes less stringent and the households can afford it. Thus, how much the households are willing to pay depends on the level of the household's income. This also implies that farmers are more willing to pay for extension if they derive greater benefits from the commercial extension services. This is why the degree of commercialization for crop, livestock and horticultural enterprises is associated with higher willingness to pay for agricultural extension services. This was consistent with the findings of Ejeta, T. T., Legesse, B., \& Aman, M., (2019); they averred that households with higher income are willing to pay more for improved irrigation water than their counterparts with lower income in Ethiopia.

Contrary to prior expectation, credit access had negatively significant influence on the willingness to pay for privatization of agricultural extension services, which is statistically significant $(P=0.085)$ at less than $10 \%$ probability level. The estimated coefficient for this variable shows that there is a negative correlation between households' access to credit and willingness to pay for agricultural extension 
Creative Commons User License: CC BY-NC-ND

Abstracted by: EBSCOhost, Electronic Journals Service (EJS),

Google Scholar, Journal Seek, Scientific Commons,

Food and Agricultural Organization (FAO), CABI and Scopus
Journal of Agricultural Extension

Vol. 24 (4) October, 2020

ISSN(e): 24086851; ISSN(Print); 1119944X

http://journal.aesonnigeria.org

http://www.ajol.info/index.php/iae

Email: editorinchief@aesonnigeria.org

services. It was noted as credit increases by 1, the likelihood that the willingness to pay decreased by $99.9 \%$. This implies that households invest their credit on other livelihood trajectories of non-farm activities without investing in agricultural production. This finding contradicts with Ejeta, Legesse, and Aman (2019) that credit utilization has a positive influence on the price farmers are willing to pay for the improved of irrigation water use in Ethiopia.

\section{Conclusion and Recommendations}

There is a significant demand for privatization of agricultural extension services to bring high-quality services. Demographic, institutional and socioeconomic factors were the determining issues for the commercialization of agricultural extension services. Age, household income, frequency of extension contacts, farm size, credit access and family size has also significant influence on privatization of agricultural extension services. Policy-makers should give emphasis for the institutionalization of privatized agricultural extension service delivery through considering number of visits, socioeconomic, and institutional factors.

\section{References}

Abate, G. T., Bernard, T., Makhija, S., \& Spielman, D. J. (2019). Accelerating technical change through video-mediated agricultural extension: Evidence from Ethiopia (Vol. 1851). Intl Food Policy Res Inst.

Angella, N., Dick, S., \& Fred, B. (2014). Willingness to pay for irrigation water and its determinants among rice farmers at Doho Rice Irrigation Scheme (DRIS) in Uganda. Journal of Development and Agricultural Economics, 6(8), 345-355.

Atinaf, M., Molla, A., Karanasios, S., \& Anteneh, S. (2020). Digitalizing Agriculture Extension Service in Ethiopia: a Design-reality Gap Analysis. In PACIS (p. 96).

Arinloye, D. D. A. A., Linnemann, A. R., Hagelaar, G., Omta, S. W. F., Coulibaly, O. N., \& van Boekel, M. A. J. S. (2016). Willingness to pay for market information received by mobile phone among smallholder pineapple farmers in Benin. Quality and innovation in food chains. Wageningen Academic Publishers, The Netherlands, 75-100.

Berhane, G., Ragasa, C., Abate, G. T., \& Assefa, T. W. (2018). The state of agricultural extension services in Ethiopia and their contribution to agricultural productivity. Intl Food Policy Res Inst.

Beyene, A. (2017). The Role of Agricultural Extension Services on Increasing Food Crop Productivity of Smallholder Farmers in Case of Atsbi Womberta Woreda, Eastern Tigray, and Ethiopia.

Cai, J., Jia, Y., Hu, R., \& Zhang, C. (2020). Four decades of China's agricultural extension reform and its impact on agents' time allocation. Australian Journal of Agricultural and Resource Economics, 64(1), 104-125. 
Creative Commons User License: CC BY-NC-ND

Abstracted by: EBSCOhost, Electronic Journals Service (EJS),

Google Scholar, Journal Seek, Scientific Commons,

Food and Agricultural Organization (FAO), CABI and Scopus

http://eoi.citefactor.org/10.11226/v24i4
Journal of Agricultural Extension

Vol. 24 (4) October, 2020

ISSN(e): 24086851; ISSN(Print); 1119944X

http://journal.aesonnigeria.org

http://www.ajol.info/index.php/iae

Email: editorinchief@aesonnigeria.org

Dhehibi, B. (2018). Power to the partners? Public Private Partnerships (PPPs) as an approach for more pluralistic agricultural extension service in Egypt.

Davis, K., Swanson, B., \& Amudavi, D. (2019). Review and recommendations for strengthening the agricultural extension system in Ethiopia. Gates Open Res, 3.

Ejeta, T. T., Legesse, B., \& Aman, M. (2019). Determinants of Farmers' Willingness to Pay for Improved Irrigation Water Use: The Case of Woliso District, Ethiopia. International journal of Rural Development, Environment and Health Research, 3(3).

Fontan Sers, C., \& Mughal, M. (2019). From Maputo to Malabo: public agricultural spending and food security in Africa. Applied Economics, 51(46), 5045-5062.

George, O., Duncan, O. G., David, M., \& Johnson, K. (2018). Livelihood assessment of avocado growing in western Kenya and its socioeconomic implications using agricultural extension services. International Journal of Agricultural Extension, 6(2), 71-79.

Gerba Leta ,Girma Kelboro ,Till Stellmacher ,Kristof Van

Assche , \& Anna-Katharina Hornidge (2017). The agricultural extension system in Ethiopia: operational setup, challenges and opportunities.

Klerkx, L., Landini, F., \& Santoyo-Cortés, H. (2016). Agricultural extension in Latin America: current dynamics of pluralistic advisory systems in heterogeneous contexts.

Modi, R. (2019). The Role of Agriculture for Food Security and Poverty Reduction in Sub-Saharan Africa. In the Palgrave Handbook of Contemporary International Political Economy (pp. 391-410). Palgrave Macmillan, London.

Rada, N. E., \& Fuglie, K. O. (2019). New perspectives on farm size and productivity. Food Policy, 84, 147-152.

Shausi, G. L., Ahmad, A. K., \& Abdallah, J. M. (2019). Factors determining crop farmers willingness to pay for agricultural extension services in Tanzania: A case of Mpwapwa and Mvomero Districts. Journal of Agricultural Extension and Rural Development, 11(12), 239-247.

Sylla, A. Y., Al-Hassan, R. M., Egyir, I. S., \& Anim-Somuah, H. (2019). Perceptions about quality of public and private agricultural extension in Africa: Evidence from farmers in Burkina Faso. Cogent Food \& Agriculture, 5(1), 1685861.

Tefera Tolera, Daniel Temesgen, D. Sundaraa Rajan ,2014.Factors affecting farmers' willingness to pay for agricultural extension services: The case of Haramaya District, Ethiopia.

Uddin, E., Gao, Q., \& Mamun-Ur-Rashid, M. D. (2016). Crop Farmers' Willingness to Pay for Agricultural Extension Services in Bangladesh: Cases of Selected Villages in Two Important Agro-Ecological Zones. The Journal of Agricultural Education and Extension, 22(1), 43-60. 
Creative Commons User License: CC BY-NC-ND

Abstracted by: EBSCOhost, Electronic Journals Service (EJS),

Google Scholar, Journal Seek, Scientific Commons,

Food and Agricultural Organization (FAO), CABI and Scopus

http://eoi.citefactor.org/10.11226/v24i4
Journal of Agricultural Extension

Vol. 24 (4) October, 2020

ISSN(e): 24086851; ISSN(Print); 1119944X

http://journal.aesonnigeria.org

http://www.ajol.info/index.php/jae

Email: editorinchief@aesonnigeria.org

Wordofa, M. G. (2019). Are farmers in Ethiopia ready to embrace cost-sharing agricultural extension approach? International Journal of Social Economics.

Zwane, E. M. (2016). Perceptions of extension advisors on privatization and outsourcing as an option for development paradigm in Limpopo Province and the lessons for future. South African Journal of Agricultural Extension, 44(2), 71-83. 